\title{
Hedging as an Important Component of the Financial Mechanism of Enterprise Management in the Automotive Cycles
}

\author{
Ajupov A.A. ${ }^{a}$ \\ Kurilova A.A. ${ }^{b}$ \\ Ivanov D.U.c \\ ${ }^{a}$ Kazan Federal University, Institute of Management, Economics and Finance, Kazan, 420008, Russia \\ bTogliatti State University, Togliatti, 445667, Russia \\ c Samara State Aerospace University, Samara, 443086, Russia \\ Email :aakurilova@yandex.ru
}

\section{Doi:10.5901/mjss.2015.v6n1s3p45}

\section{Abstract}

The Russian automotive industry is facing increasing competition from world leading manufacturers. In these circumstances, it becomes important to achieve optimum prices without affecting the properties of produced consumer vehicles. A possible way to optimize - hedging through the purchase of exchange and OTC derivatives. Practice shows that the leading automotive corporations make extensive use of derivative financial instruments to hedge the cost of optimizing the currency and commodity contracts, interest payments. This practice can be applied to the Russian automobile enterprises in this paper, we consider the practical aspects of risk hedging.

Keywords: automotive industry, the industry for the production of vehicles, hedging, derivatives, financial derivatives, cyclic, budgeting, hedging system.

\section{Introduction}

Russian automobile enterprises are experiencing a negative impact primarily growth in steel prices, which range from 70 to $80 \%$ by weight of the car.

At the same time lately has been a sharp rise in steel prices - from 2000-2012's prices rose more than 3 times.

Given the high proportion of steel in the weight of the car, the increase in steel prices leads to an adequate increase in the cost of production automobile. At the same time the increasing competition among the car manufacturers and the growth of production in the first place in China makes it impossible to appropriate compensation cost growth increase in the price for the products.

It should be noted that the financial results of enterprises automotive affect not only the increase in steel prices, but also fluctuations in the value of foreign exchange resources. The effect increases with the proportion of imported components in the value of the car. So the novelty of the domestic automotive industry - Lada Grant - 15-20\% consists of imported components, and in value terms, the share of $30-35 \%$ of the value of the car. It is obvious that as the integration of the Russian car manufacturers in the industry worldwide impact of foreign currency translation in the direction of the weakening of the national currency will increase.

\section{Theory}

It should be noted that the weakening of the national currency and an increase in foreign exchange rates occurs in times of crisis for the Russian economy periods, which are usually accompanied by a fall in car sales, a decrease in the volume of consumer credit and other negative consequences. Compensation for losses automaker at this time due to the price increase is not possible, as the market at this time, "lying on its side" and any, even a slight increase in product prices will cause an even greater drop in sales.

However, manufacturers face and reverse the effects of currency fluctuations related to the strengthening of the national currency. This occurs when exporting cars. For example, at the end of 2010 OAO "AvtoVAZ" sold 43,839 units. Car domestic production for export, accounting for $8 \%$ of total sales of products of JSC "AvtoVAZ". Geography of 
deliveries of vehicles of "AvtoVAZ" export covers almost all regions of the world - from the CIS to Europe and Latin America. Increase in the value of the national currency leads to lower yields concluded export contracts and loss of "AvtoVAZ".

In addition to rising steel prices and changes in exchange rates, the negative impact on the financial and economic activity of the enterprises of motor has a positive change in interest rates (see Fig. 1)

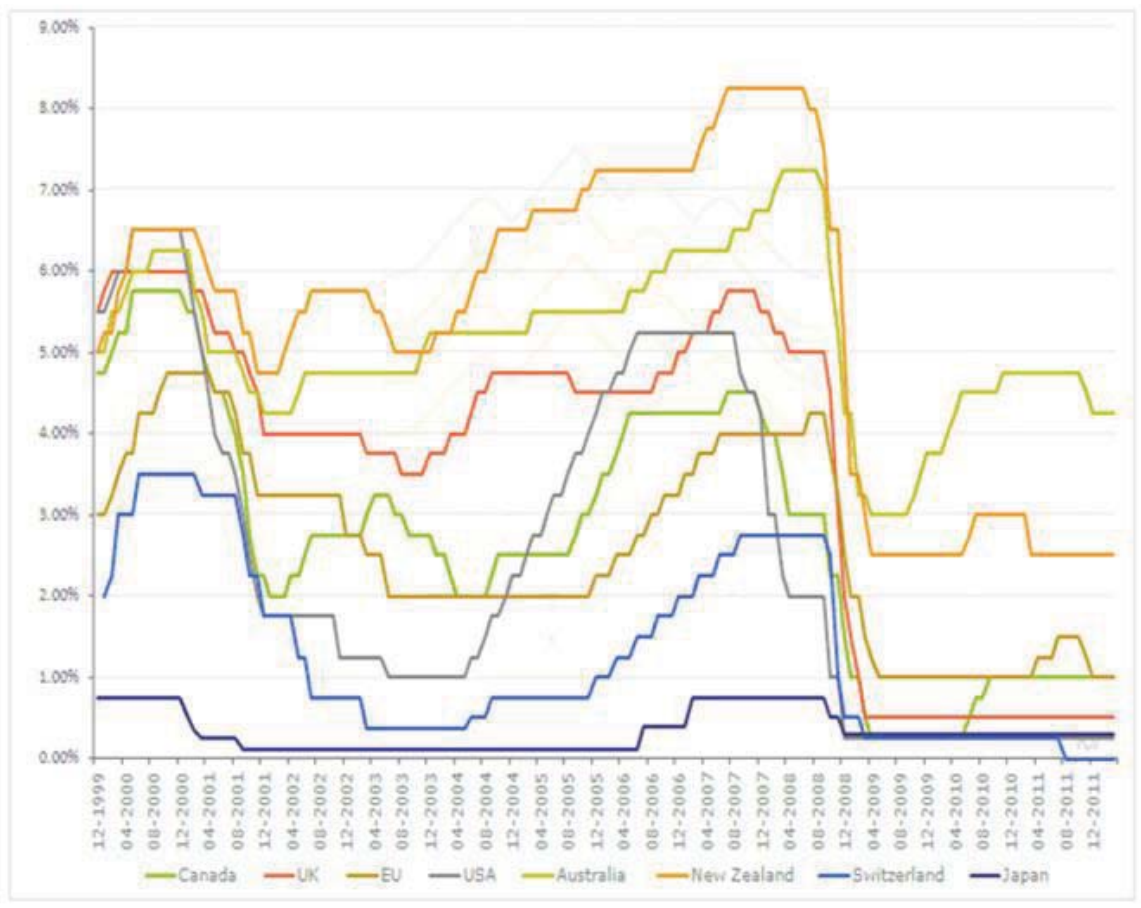

Figure 4 - Change in interest rates c 1999-2012

As is the case with the growth rate of the foreign currency interest rate growth begins in the most "wrong" time - during the progressive crisis phenomena in the economy.

Normally at this point in the warehouses of dealers residues accumulate unsold products, suppliers of raw materials and components are beginning to feel the lack of working capital, reduce the supply of products under the terms of payment by installments, requiring prepayment.

At these moments, the debt burden on the company automobile, which are a unique center for the application of credit load the entire business process, critical increases and growth in interest for the loan servicing existing debt makes software critical for the life of the enterprise. This can lead to destabilization of the financial condition of the company, a decline in its liquidity and bankruptcy of the enterprise. A striking example - the crisis of 2008-2009, the consequences of which are: the bankruptcy of the largest automobile manufacturer - General Motors (General Motors), technical bankruptcy of a member of the American trio - Chrysler (Chrysler), the financial problems of the German Opel (Opel) and Russian AvtoVAZ, bankruptcy of the Swedish SAAB (SAAB) and so on. should be noted that the automotive industry has faced in 2008-2009 with the biggest crisis in the history of the industry, which is one of the reasons - high debt load and failure of service due to a sharp increase in the cost of financing. Debt crisis automakers was overcome by government support. For example, to rescue AvtoVAZ Russian government spent 70 billion rubles, and the majority of these funds 54 billion rubles were spent on repayment of current debt in the form of a loan, issued bonds and notes.

\section{Results}

In general, the Russian automobile enterprises in their business activities there are many risks - the risk of compliance with contractual relations in the supply of components and raw materials to the risks associated with changes in the legal system and force majeure. Consequences of most of these risks are minimized by means of selecting contractors, contracts with insurance companies, the use of legal support and so forth. 
Out of the risk should be allocated the risks associated with the rising cost of raw materials, changes in exchange rates and interest rates, for the following reasons.

Firstly, these risks are an effective system to reduce losses by hedging these risks in financial and commodity markets through transactions with derivative financial instruments.

Second, the risks are of a periodic, cyclical nature, which explains the periodic opposite changes in asset prices in financial and commodity markets.

Third, hedging these risks without the use of OTC and listed derivative financial instruments is virtually impossible.

In this case, under the hedging understand insurance, reducing the risk of loss due to adverse for buyers or sellers changes in market prices of goods in comparison with those taken into account in the contract.

Table 1: Comparative characteristics of derivative financial instruments that can be used to hedge risks

\begin{tabular}{|c|c|c|}
\hline Tool & Advantages & Disadvantages \\
\hline Forward contract & Availability & $\begin{array}{l}\text { Lack of liquidity, as it is an OTC financial instrument. } \\
\text { Potentially unlimited loss on the transaction. } \\
\text { Risk of default of the contract, there is no system security } \\
\text { risks. }\end{array}$ \\
\hline Futures contract & $\begin{array}{l}\text { Availability, liquidity, a high probability of the } \\
\text { transaction, validate the warranty exchange }\end{array}$ & Potentially unlimited loss on the transaction. \\
\hline Option & $\begin{array}{l}\text { Availability, liquidity, a high probability of the } \\
\text { transaction, validate the warranty exchange (it } \\
\text { this exchange instrument), the possibility of } \\
\text { waiver of the transaction by the buyer of the } \\
\text { option }\end{array}$ & Expenditure on payment of premium to the option seller. \\
\hline Swap & Availability & $\begin{array}{l}\text { Lack of liquidity, as it is an OTC financial instrument. } \\
\text { Potentially unlimited loss on the transaction. } \\
\text { Risk of default of the contract, there is no system security } \\
\text { risks. }\end{array}$ \\
\hline
\end{tabular}

To minimize the additional cost of paying the loan in foreign currency automaker may use derivatives exchange market. In this case, the automaker could buy a derivative, or a combination of several financial instruments with terms of delivery dollars at the time of interest payments on the loan and the date of payment of principal. Thus, the automaker risks associated with a possible increase in the USD exchange rate would be reduced to a minimum. Selection of a particular hedge currency risk will depend on the state of the system hedging specific manufacturer. In the presence of an effective system of hedging may use futures contracts, in the absence of such a system is the most effective and safe in terms of the risks associated with the acquisition of a derivative security is to buy an option or entering OTC swap transaction.

For the automotive industry, exporting products to other countries, is characterized by the loss associated with the reverse situation - the growth rate of the ruble against the dollar. Thus, automakers typically faced with two varieties of currency risk - the risk of depreciation and appreciation of the national currency. In this case, one currency position may prevail over the other, and in some cases foreign exchange position of the company can offset each other.

Hedging increase in the cost of raw materials and components may also be effected by means of derivatives. However, in contrast to hedge currency risk, hedging increased cost of raw materials on the Russian stock markets for car manufacturers is rather difficult due to lack of necessary trade financial instruments such as contracts for aluminum and steel, as well as the low liquidity of the markets.

By using derivative financial instruments that are traded on international markets, the automaker can hedge the risks increase in the cost of raw materials by buying derivatives that are similar to the above example with the hedging of currency risks.

Given a certain complexity in the organization of the process of hedging the rising cost of raw materials through the purchase and sale of derivative financial instruments on the international financial markets, initially Russian automakers can recommend the execution of OTC contracts with Russian banks that offer effective ways of hedging commodity risks.

For this purpose between the Bank and the automaker must be enclosed model contract ISDA, defining the rights and obligations of the parties in the course of hedging risk positions of the client. A significant advantage of this option is the lack of actual hedging transactions in the market on the part of the client, ie Bank shall purchase or sale of exchange tool in its own name on behalf of a client.

Typically, banks are given three options hedging changes in the cost of raw materials: 
- Price fixing (swap);

- $\quad$ To guarantee the maximum level of prices (optional);

- Limiting the potential price fluctuations (collar).

Table 2: Comparative options hedging changes in the cost of raw materials as a result of the agreement to enter into an OTC ISDA

\begin{tabular}{|l|l|l|}
\hline Tool & Advantages & Disadvantages \\
\hline Fixing (swap) & $\begin{array}{l}\text { Protection rates, purchased } \\
\text { asset does not imply } \\
\text { bonuses and commissions. }\end{array}$ & Losses as a result of falling asset prices. \\
\hline Purchase warranty (optional) & $\begin{array}{l}\text { Protection rates, purchased } \\
\text { asset. }\end{array}$ & $\begin{array}{l}\text { The high cost of the strategy by the payment of premiums and } \\
\text { commissions. }\end{array}$ \\
\hline limiting fluctuations (Collar) & $\begin{array}{l}\text { Relatively small values of } \\
\text { financial instruments. }\end{array}$ & $\begin{array}{l}\text { The upper limit is often higher than the budget price possible losses } \\
\text { as a result of falling asset prices lower limit of the corridor. }\end{array}$ \\
\hline
\end{tabular}

Consider the example of hedging the rising cost of raw materials by the example of Russian manufacturers of aluminum metal that is gaining share in the cars produced in the world is gradually replacing the traditional steel.

Russian automakers pay for the supplied aluminum suppliers in accordance with the average quotation of aluminum on the Exchange LME. To avoid this, the company can hedge risks through the purchase of OTC contract ISDA. Consider the economic impact of the various options hedging.

The first option is to hedge price fixing, i.e. finally, swap (SWAP). The purpose of this transaction to fix the price of purchasing the product at a certain level for a specified period. If the market price of aluminum during a specified period is lower than the fixed price, the buyer of the swap pays the seller the difference between the fixed rate swap and the market price.

Another option hedging - buying a call option (call), ie fixing maximum prices. By purchasing an option, the customer gets the right but not the obligation to make a purchase of an asset at a specified date at a predetermined price (the strike price). If formed price at expiration the market price is more favorable level of the strike, the client waives the strike and making the deal at the market price. Buying an option involves the payment of a customer the option premium. In contrast to the swap agreement, the option buyer not only protects against unfavorable changes in prices, but also allows you to "participate" in a positive development of the market for the client.

The third option proposed by Russian banks hedging is the purchase of a call option (call) and sale of a put option (put). This achieves fixing the market price of the purchased product in a certain guaranteed corridor during a specified period. At the time of the transaction the customer pays the bank a one-time insurance premium. Maybe pick up the boundaries of the corridor so that the insurance premium will be equal to zero. The combination of put and call with a minimum premium achieves almost ideal for the enterprise version of the hedge. So, if the market price is higher than the fixed price (or rather the boundaries of the corridor), the bank will pay the difference between the fixed and the market price. If the market price during a specified period would be within the boundaries of the corridor, the obligations under the option will be reset without payment of additional premiums and commissions. If the price falls below the corridor, the company will incur unlimited losses.

For a final decision on the choice of an option hedging is necessary to assess the price risk, for example by the method of "Monte Carlo" using time series, characterized by fluctuations in prices for a given asset.

\section{Conclusions}

At present, the domestic automotive industry is at a critical portion of his development, Russia's accession to the WTO, increased competition makes paramount speedy work to optimize all types of costs not only by the trivial reductions on all counts but also by searching for painless methods of production and consumers to reduce them. One option is to hedge the risk of rising raw material costs and financing, as well as changes in exchange rates. Creating a system of hedging by domestic enterprises automobile - it is one of the most effective ways to optimize costs without sacrificing consumer properties of products. 


\section{References}

Magee, S. The effect of foreign currency hedging on the probability of financial distress // Accounting and Finance, 53 (4), $2013, \mathrm{pp}$. 1107-1127.

Ankirchner, S., Kratz, P., Kruse, T. Hedging forward positions: Basis risk versus liquidity costs // SIAM Journal on Financial Mathematics, 4 (1), 2013, pp. 668-696.

Wong, K.P. A note on exports and hedging exchange rate risks: The multi-country case // Journal of Futures Markets, 33 (12), $2013, \mathrm{pp}$. 1191-1196.

Kellner, R., Gatzert, N. Estimating the basis risk of index-linked hedging strategies using multivariate extreme value theory // Journal of Banking and Finance, 37 (11), 2013, pp. 4353-4367

Ruf, J. Negative call prices // Annals of Finance, 9 (4), 2013, pp. 787-794

Kaeck, A. Hedging surprises, jumps, and model misspecification: A risk management perspective on hedging s\&p 500 options // Review of Finance, 17 (4), 2013, pp. 1535-1569.

Elices, A., Giménez, E. Applying hedging strategies to estimate model risk and provision calculation // Quantitative Finance, 13 (7), 2013, pp. 1015-1028.

Byoun, S., Kim, J., Yoo, S.S. Risk management with leverage: Evidence from project finance // Journal of Financial and Quantitative Analysis, 48 (2), 2013, pp. 549-577.

Yartiev A.F., Tufetulov A.M. Effect of license holder's cost-flow on long-term development of oil industry // Mediterranean Journal of Social Sciences vol. 5 № 24, November 2014, pp. 417-420

Valitov, S.,Ibragimov, M.,Ibragimov, R. (2014). Elasticity analysis of unemployed people quantity in relation to gross domestic product of Russia. World Applied Sciences Journal, 30 (10), pp. 1357-1364.

Ablaev I.M., Khovanskaya E.S. Essence and Economical Substance of Innovative Cluster in Territorially Localized Business System// Mediterranean Journal of Social Sciences.- Vol.5, No12, (2014)-pp.159 - 162. 